\title{
"You have to teach to your personality": Caring, sharing and teaching with technology
}

\author{
Chris Shelton \\ University of Chichester, United Kingdom
}

\begin{abstract}
Studies of teachers in higher education have acknowledged the relationship between teaching and teacher identity. Teacher identity is seen as dynamic, context-specific, and encompassing a teachers' sense of meaning, values and self-esteem. This article considers the relationship between the values dimension of teacher identity and the use of technology. Using qualitative data from a multisite case study, it explores three aspects of the relationship between values and technology in teaching: firstly, the extent to which technology allows university teachers to share their values and their personality with students; secondly, the way in which technology affects the performance of teaching; thirdly, the ways in which teachers enact their care for and commitment to students though technology-mediated means. The article suggests that technology can be used in ways that teachers feel support or hinder their ability to communicate their values and shows how an individual's use of technology may be shaped by aspects of their identity as a teacher.
\end{abstract}

\section{Introduction}

The use of technology is now an important part of teaching and learning in higher education. To a greater or lesser extent, university academics make use of a range of technologies to supplement or support their teaching activities. Previous studies have shown that an individual's use of technology is situated within specific institutional and disciplinary contexts (Buchanan, Sainter, \& Saunders, 2013; Shelton, 2014) and influenced by their beliefs about learning and teaching (Bain \& McNaught, 2006) and about technology (Steel, 2009). In addition, Hanson (2009) suggests that the use of technology can affect a teacher's academic identity and, more recently, Perrotta (2017) has highlighted the role of emotions in school teachers' engagement with technology. Veletsianos and Kimmons (2013) suggest that the "influence and pressures of technology adoption on the academic self have not been examined" (p. 49). This article contributes to understanding the relationship between an individual teacher's personality and their use of technology by focussing on the "values" dimension of teacher identity.

\section{University teacher thinking and beliefs}

There is now a substantial body of research that considers the connections between an individual teacher's beliefs and thinking and how they use technology (e.g., Bain \& McNaught, 2006; González, 2012; Newland \& Byles, 2014). Hativa and Goodyear (2002) note that teaching in higher education is a professional, complex, cognitively demanding and creative activity, and Bates and Poole (2003) suggest that choices about how to use technology are completely dependent on a teacher's beliefs. A teacher's attitudes and beliefs about technology differ from those of their students (Kregor, Breslin, \& Fountain, 2012) and are reflected in their designs for learning experiences (Bennett, Agostinho, \& Lockyer, 2015).

It has been argued that effective technology use is associated with constructivist conceptions of learning (Becker \& Ravitz, 1999), and the use of e-learning, in particular, can make such pedagogic beliefs more visible and explicit (Kirkwood, 2009). Ferguson (2004) suggests that teachers hold either teacher-centred or student-centred pedagogic beliefs and that these contrasting views of teaching and learning lead to different ways of using technology. Building on the identification of "conceptions of teaching" (Kember \& Kwan, 2000), Roberts (2003) and Gonzalez (2009) identified teachers' conceptions of online teaching along a scale from content-centred to learning-centred. However, while conceptions of teaching are assumed to be stable, teachers may exhibit inconsistencies between their stated pedagogical beliefs and their reported practices with technology (González, 2012; Owens, 2012). 
However, Bain and McNaught (2006) suggest that dichotomies of belief about teaching are insufficient to understand how teachers make decisions about technology and that although individual practices may appear to contradict a claimed belief, these may, in fact, be consistent once the context of the teacher's whole belief system and teaching environment are taken into account. Steel (2003; 2006) develops this by exploring the relationship between beliefs about learning and teaching, and beliefs about the nature of technology. Steel showed that differing beliefs influenced course design, and her case studies describe how one person's view of teachers as experts and students as apprentices led to different uses of technology than another's view of teacher and student as collaborative partners. Campbell (2005) suggests that it is the alignment between innovation and the teacher's "core values" (p. 311) that is key. For Campbell, adopting technology may be an "intensely personal process" (p. 311) through which beliefs may be adjusted but only under particular conditions, including the existence of a social community where collaborative conversations occur and assumptions may be challenged.

Research into teacher beliefs suggests that cognitive decision-making about teaching with technology reflects relatively stable sets of beliefs. In contrast, other researchers have emphasised the role of teacher identity as a dynamic and changing construct.

\section{Teacher identity}

The professional identity of school teachers emerged as a significant focus of research in the 1990s although early studies did not always define identity clearly or consistently (Beijaard, Meijer, \& Verloop, 2004). Since these initial studies, there has been a shift from understandings of identity as a single, stable whole to conceptions of identity as a dynamic process whereby identities are formed and re-formed (Skelton, 2012a) and may be more or less stable depending on the teacher' professional or personal context (Day, Kington, Stobart, \& Sammons, 2006). Thus, Beijaard et al. suggest that identity can be seen as "an answer to the recurrent question: 'Who am I at this moment?'” (2004, p. 108). A significant aspect of teacher identity is the role of emotions and the interaction between the cognitive and emotional aspects of teachers' professional identity (e.g., Day \& Leitch, 2001; Uitto, Jokikokko, \& Estola, 2015). Beijaard et al. (2004) identified four features of school teachers' professional identity: identity is an ongoing process - dynamic rather than fixed; it relates both to a person and their context; it consists of sub-identities (that must not conflict); and teachers have agency in how they form and express their identity.

These four features of school teachers' identity can also be found in studies of academic identity in higher education. For example, the dynamic and contextual nature of identity is noted by Henkel (2005), who suggests that identity is "shaped and reinforced in and by strong and stable communities and the social processes generated within them” (p. 157). Henkel (2005) identifies three dimensions of academic identity: sense of meaning, values and self-esteem, and signals the impact of an individual's institution and discipline on these. Other contextual factors that influence academic identities in higher education include students' evaluations of teaching (Hativa \& Goodyear, 2002) and changes to the higher education sector (Nixon, 1996).

In parallel to Beijaard et al.'s (2004) concept of sub-identities, Kreber (2010) describes how, due to their membership of multiple communities, academics in higher education construct multiple identities that contribute to an overall academic identity. For example, Nixon (1996) suggests that academics may have identities as a researcher, a teacher or an administrator. However, research into academic identities in higher education has mostly focused on experiences of neo-liberalism rather than specifically on teacher identity (Hockings, Cooke, Yamashita, McGinty, \& Bowl, 2009). Although Kreber (2010) suggests that an academic's teacher identity does not exist independently from their overall academic identity, it is, she argues, plausible to explore and describe teacher identities separately. And while Roche and Marsh (2000) suggest that teacher identity is independent of an individual's research self-concepts, Skelton (2012a) notes how individuals may struggle to reconcile their teacher identity and the research culture of their university. 
Like academic identity more broadly, teacher identity is "rooted in the cultural context of the university" (Nevgi \& Löfström, 2014, p. 182) and influenced by an individual's educational experiences, subject community and beliefs about themselves and their students (Hockings et al., 2009). Lankveld, Schoonenboom, Volman, Croiset, and Beishuizen (2017) describe four contextual factors that affect the development of teacher identity: the higher education sector, immediate work context, contact with students, and staff development. The impact of these contexts can be seen in the work of Skelton (2012b), who shows how conflicts can occur between the values held by individual teachers and those held by others at different levels of the higher education sector. For Skelton, teachers demonstrated "strategic compromise" - "accepting structural constraints beyond one's personal control whilst holding private reservations about their pedagogical impact.” (p. 11). According to Lankveld, Schoonenboom, Volman, Croiset, and Beishuizen (2017), teacher identity is developed and maintained through processes relating to an individual's sense of appreciation, connectedness, competence, commitment and their future career. The fourth of these, commitment, refers to teachers' "deep personal interest in teaching the next generation” (p. 9) and their care for students.

In summary, academic identity is multifaceted and encompasses academics' sense of meaning, values and self-esteem. From this perspective, an academic's teacher identity can be understood as a sub-identity of their broader academic identity that can sometimes come into conflict with the other aspects of their identity. Teacher identity is dynamic rather than fixed and influenced by context and discipline. Caring for and commitment to students can be a key aspect of the values dimension of a teacher's identity.

\section{Technology and teacher identity}

Henkel's (2005) three dimensions of academic identity (sense of meaning, values and self-esteem) can be usefully applied to analyse the literature regarding technology and identity in higher education. In terms of the sense of meaning dimension, some researchers have suggested that the introduction of new technologies into teaching can sometimes be viewed as a threat to a teacher's identity. For example, an academic's identity and their understanding of the meaning of their work may be threatened by the proliferation of online access to sources of knowledge (Lynch, 2002). Hanson (2009) takes this further and notes how, for some individuals, the status of their academic knowledge had been threatened by the growth in access to electronic sources and this had forced them to accede a position as knowledge gatekeeper. Simultaneously, her participants reported a loss in teacher presence compared to their previous practices due to the nature of teaching online and the constraints of using electronic presentations. Hanson sees these changes as threats to teachers' "ontological security” (p. 561) and notes how, when faced with such changes, her participants fell back on their identity as successful face-to-face teachers and used this to justify their reluctance to use e-learning.

The self-esteem dimension of teacher identity may be affected if an individual perceives technology as constraining their personal agency. New technology may be seen as a potential threat to a teacher's authority (Bakioglu \& Hacifazlioglu, 2007) or as leading to a sense of loss of control, for example, in online group work compared to face-to-face group activities (McConnell, 2000). Johnson (2012) suggests that if a technology is introduced by managerial coercion rather than professional choice, this can result in a teacher feeling a loss of professional autonomy. In these circumstances, self-presentation can become an important preoccupation for teachers. Goodyear (2002) describes how teachers spend a great deal of time thinking about and preparing their contributions to online discussions, but may not want this effort to show. He also notes how the pressure to keep up with discussions can be a source of anxiety for teachers. The tensions involved in such self-presentation, while maintaining relationships with students and establishing personal boundaries, is particularly apparent in teachers' use of social media (see, for example, Veletsianos \& Kimmons, 2013).

The values dimension of teacher identity is less commonly acknowledged in the literature concerned with technology in higher education. It is noted that, if teachers are compelled to adopt new technologies, this can lead to conflict between their beliefs about teaching and learning and their practice (Shelton, 2014; Westberry, McNaughton, Billot, \& Gaeta, 2015). This can lead to teachers feeling "disconnected, both pedagogically and emotionally" from their own teaching (Westberry et al., 2015, p. 112), and even teachers who are confident 
and enthusiastic about technology may feel the need to reassert their identity. These examples show how Henkel's (2005) three dimensions overlap: conflicts about the meaning of their beliefs and practice are often also value-laden and can affect self-esteem. Values also impact decisions about technology; for example, McShane (2004) investigated early adopters who had made choices about how they combined online and traditional teaching methods based on their own particular values and beliefs. McShane suggests that these teachers retained traditional lectures to "reinforce their centrality in the teaching-learning process, and their control of the learning and learners" (p. 14).

In contrast, Clegg (2011) rejects the idea that technologies relate to academic identity in a simple way, suggesting that there is little empirical data about their impact. In discussing her own use of email, Clegg shows how email not only "entrenches audit and managerialism" (p. 176) but also creates intimacy with distant colleagues and friends. Clegg resists a technological determinist view that would see academic identities changed by new technology but instead suggests a view of technology as embedded social practice that academics both work with and against.

In summary, there is a relationship between a teacher's use of technology and all three of Henkel's (2005) dimensions of academic identity. Technological developments may be perceived by teachers as potentially leading to a change in their role as a teacher or to the status of their academic knowledge and thus as a threat to the meaning of both their teacher and academic identities. It can also be associated with feelings of loss of control or authority and hence affect a teacher's self-esteem. Using new technologies may also raise questions for teachers about the value of their teaching, and their relationships with students or colleagues.

However, although there is a growing body of research into the relationship between technology and teacher identity that focuses on the status and authority of teachers in higher education, fewer studies have focused on the ways in which technology relates to the values aspect of teacher identity. This article is intended to contribute towards addressing this gap in the literature. In particular, it focuses on the relationship between the ways in which technology enables or hinders teachers to express and maintain their values, for example, their care and commitment to students.

\section{Method}

This article reports on data collected as part of a qualitative, multisite case study investigating teacher's thinking about teaching with technology in higher education. The study had several objectives including to identify how university teachers' thinking about using technology was shaped by social and organisational contexts (see Shelton, 2018). Teacher identity is a key aspect of teacher thinking and this article reports on the results of the study with regard to identity, personality and values - a key theme to emerge from the data.

The research used a multisite case study approach (Yin, 2003) in order to provide a detailed account of the participants and their settings. In order to identify suitable participants, data from an earlier survey of UK universities was used. This survey had invited responses from participants who were willing to take part in interviews about their use of technology, and three universities that varied in terms of size, campus location, student intake and subjects taught were chosen as sites for the research. These were modern, multi-campus universities in different cities in England. From these institutions, potential volunteers were contacted to ensure that the interview sample varied according to age, gender, seniority, teaching experience and subject discipline (see Table 1). The sample was also designed to include both high and low users of technology as previous studies had often focused on early adopters of technology and enthusiasts (Hanson, 2009). In order to maintain participant confidentiality, interviewees have been assigned a single letter code. 
Table 1

\begin{tabular}{llllll} 
Interview sample & \multicolumn{1}{l}{} \\
\hline Participant & University & Subject discipline & Gender & Age & Role \\
\hline A & 1 & Nursing & Female & $40-49$ & Senior lecturer \\
B & 2 & Psychology & Male & $50-59$ & Senior lecturer \\
C & 2 & Biological sciences & Male & $40-49$ & Senior lecturer \\
D & 2 & Education & Male & $50-59$ & Professor \\
E & 3 & Education & Female & $30-39$ & Senior lecturer \\
F & 1 & Law & Male & $30-39$ & Lecturer \\
G & 3 & Childhood studies & Female & $40-49$ & Lecturer \\
H & 3 & English & Female & $40-49$ & Senior lecturer \\
I & 2 & Subjects allied to & Female & $40-49$ & Senior lecturer \\
& 1 & medicine & & & Reader \\
J & 3 & Creative arts \& design & Female & $50-59$ & Senior lecturer \\
\hline
\end{tabular}

Each participant was interviewed on multiple occasions by the author in order to provide interviewees with time to become more comfortable with the research process and the researcher. Each interview had a specific focus and approach and was piloted with a university teacher who was not part of the sample. The first interview used a semi-structured format to explore participants’ perceptions and beliefs about technology and their context. The second interview generated a narrative of the participants' use of technology over their career, and the third used simulated recall to prompt a discussion about a particular technology and the context in which it was used.

All interviews were recorded and transcribed. Resulting transcripts were sent to participants to allow them to check for accuracy and to make any clarifications they felt necessary. In order to improve the reliability of the findings, initial analysis of the interviews began after the first interview with each participant so that any tentative initial conclusions could be raised and discussed at subsequent interviews. In addition, at the end of the third interview, participants were asked for their reaction to points raised by other participants.

Flick (2009) suggests a “thematic coding” (p. 318) approach to analysing multiple case studies. In this approach, a deep analysis is conducted to code a single case which is intended to result in a thematic structure that can be used to underpin the analysis of subsequent cases and modified as new elements emerge. This was conducted through an initial open coding that aimed to construct analytic codes through a close reading of the text and to "mine early data for analytic ideas to pursue in further data collection and analysis" (Charmaz, 2006, p. 44). This stage is similar to a grounded theory approach, where codes are created by defining what emerges from the data rather than applying preconceived categories to the text. However, in contrast to the grounded theory approach, for this study, the codes resulting from the analysis of the first case were then related to the project's research aim and theoretical background to create a set of analytical categories to use in the next stage of coding. This included codes relating to identity, teaching style and personal values. During the second stage of coding, these were applied across all interview transcripts. Once all the interviews had been coded, key themes were identified through collecting all of the data relating to each code. The resulting themes have been used to structure the findings below.

The research approach followed the British Educational Research Association’s (2011) “Ethical Guidelines for Educational Research” and full ethical approval was given through the researcher's institution's ethical approval procedure. Participation in the research was voluntary and participants were free to withdraw from the research at any point. Each participant was fully informed of the purpose of the research prior to the interviews and gave written consent. 


\section{Findings}

Evidence from the interviews confirmed that the participants in this study had a strong sense of commitment to their students and demonstrated this in their teaching. In particular, their values were communicated through intentionally sharing their personality with their students; views of communication and performance; and in their care and concern for their students. The data demonstrates that uses of technology had an important role in each of these three areas and that these uses were shaped by the participants' values and intentions.

\section{Sharing: Communicating values and personality through technology}

Throughout the interviews, it was clear that all participants wished to inspire their students and develop understanding and enthusiasm for their subjects. But they achieved this in different ways, and for some participants, how they went about this depended on their personality. This was stated most explicitly by Interviewee B:

You have to teach to your personality and if you don't, if you try and be something you're not, then I think you will fail. (B)

For Interviewee B, sharing enthusiasm was at the heart of good teaching and he believed that technology helped him to communicate his enthusiasm. It also helped him to communicate other aspects of his personality; for example, he described how using audio recordings when marking student work rather than written comments allowed him to use intonation to say things that might otherwise be misinterpreted. Similarly, Interviewee I believed that video could be used to share a teacher's emphasis and intonation and that this would benefit her students.

How teachers used their virtual learning environment (VLE) could also communicate something of their personality. Interviewee J discussed making her VLE page welcoming through its orange colour scheme:

I thought orange is just warm, it is welcoming and warm but still bright and sunny. So, I just thought it gives a glowy feel to it and it's just, I just thought it will make people feel warm and comfortable.

In contrast, Interviewee K shared a different aspect of his personality in his VLE page:

It looks a little bit like this desk. So there's like, there's files everywhere and the content of all those are fine but it's not prettily designed or anything. There's logic and there's method in there but no flowers or anything like that.

He did not make a conscious effort to make the page unattractive but equally did not try to make the site appealing. He contrasted this to other colleagues:

But I've seen, especially some of the females that theirs just look like lovely, ideal home exhibitions of pictures and images and different colours. I just think, what on earth is that, just get the files up there. (K)

Despite the stereotype implied in this quote, as the data in the following sections will show, a concern with visual presentation was sometimes important for both male and female teachers.

In contrast, technology could be seen as hampering an individual's ability to share their personality with students; for example, Interviewee A felt that her personality was not reflected in her online teaching: 
Because the whole point of my teaching is, a lot of it is the personality, the enthusiasm you have for your subject and I can't get that enthusiasm over online and I find that really frustrating. (A)

For Interviewee A, the activities she set online did not communicate her passion for the subject she taught and she felt that despite her efforts, her teaching could become boring.

Aspects of an individuals' character and personality could also affect the kinds of technologies that they chose to use. For example, Interviewee B felt that he was "too disorganised to be someone who could effectively use an e-portfolio" (B). Another aspect of Interviewee B's personality was that he considered himself to be "fundamentally lazy". As a result, he tried to make learning as easy as possible and gave the example of a podcast that could be listened to while "lying on my bed with my eyes shut and learning - how good is that".

Interviewee $\mathrm{C}$ also expressed his enthusiasm for his subject through his teaching:

I think it's fascinating, I think it's interesting, bugger the students. I'm enjoying myself, what couldn't be fun about this. (C)

He shared this enthusiasm and other aspects of his personality through technology, for example, through lighthearted emails and announcements. These were intended to engage students, and he contrasted them with the emails he had received from other module leaders that were matter-of-fact and terse. The emails were an extension of the "outrageous" jokes and comments that he liked to use in his teaching sessions even though he sometimes wondered if he went too far. As module emails were automatically copied to his line manager, he knew that his manager was reading these messages too and had commented on them, but he tried not to worry about anyone sharing or misinterpreting his emails:

I probably, almost certainly, purposefully choose not to think about it because I think if I did ... I wouldn't be as silly, I would be more self-conscious, I think, of what I said. (C)

The extent to which an individual believed that they could express their identity through technology was an important aspect of how satisfied they were with their use of technology in their teaching. Those who felt that technology hampered the communication of their personality or warmth were more reluctant to use technology, while those who were more comfortable with their ability to share their identity through technology were happier to continue using it.

\section{Teaching: Technology-mediated communication and performance}

Several participants described their approaches to teaching in terms of individual "styles" and "performance" and used these to justify their use or non-use of technology.

Interviewee $\mathrm{F}$ taught part-time while practising as a barrister and transferred the skills from this profession into his teaching:

Given the day job is obviously entertaining the juries, the job is entertaining the troops in the student context. (F)

Although Interviewee F was clear about the differences between these contexts and did not treat his students as if they were a jury, he did believe that the communication skills and ability to engage his listeners that were vital to his success as a barrister were usefully transferred to his teaching. He characterised his style as consisting of highly structured teaching sessions supported by very detailed notes for both him and his students. He believed that developing this structure had enabled his teaching to become more active and dramatic while ensuring students' detailed understanding of the topic. He also believed that this style of teaching was most effective without using technology. 
The transfer of experiences outside of teaching was also important to Interviewee J, who had previously been a disc jockey. This was reflected in how she spoke about her teaching as performance:

Particularly those really big lectures you do sort of present them as a sort of mini-production, but the only problem is that you only do one time and you have to wait a whole year to improve it. If you're in theatre you do one night then the next night you do it again and you make it better. So, yes, I always feel there is a bit of a pressure there to get it right first time round. (J)

Her concern to "get it right" and produce a good performance manifested itself in her use of technology. While she did not think that teaching as performance was a new phenomenon - she described teachers who had been "quite flamboyant with their use of blackboards" - she did feel that something was different when working with digital technology.

Interviewee B described how his view of the teaching "performance" had changed over his career. Early in his career, he had believed that students wanted a "perfect performance" and this feeling of student expectation had affected his teaching. However, as he had become older and more experienced, he felt that he could "get away with an awful lot more as an old man than you do as a young man" and "played to that" believing that if he was "personable" then students would "forgive you almost anything".

Concerns about performance could also lead to a teacher abandoning the use of a technology. Interviewee D described having previously used PowerPoint to appear up to date and "flash" when promoting courses but stopped this after becoming convinced that "flashness" was associated with insincerity. He had become embarrassed by his PowerPoint presentations and had come to believe that they no longer had any impact because everyone else was using PowerPoint too.

Technology played a central role in some participants' teaching styles. Interviewee C described his teaching style as "image focused" and he spent a great deal of time finding suitable images for his PowerPoint slides. He created very long PowerPoint files with many images to discuss rather than a great deal of text and believed that this gave him more flexibility to respond to students' questions and comments. In his case, the opportunities to source images online had reinforced and helped to produce this teaching style.

A dislike of text-heavy PowerPoints was common. Interviewee $\mathrm{H}$ also provided very "image heavy" PowerPoint slides and acknowledged that this was a personal preference:

I don’t like very text-heavy PowerPoints for myself. So, we've all got different styles, haven’t we? (H)

For Interviewee $\mathrm{H}$, her dislike of too much text had to be kept in balance with an "anxiety about covering every angle". This was achieved through comprehensive VLE pages and providing separate lecture outlines to accompany her PowerPoint slides. She contrasted this with a colleague's more pared down and streamlined teaching style.

Interviewee B described his teaching style as "chaos and madness" and suggested that individual teachers needed to find their own style of teaching. This was also reiterated in the way that interviewees $\mathrm{J}$ and I both justified their use of technology in terms of things that worked for them while acknowledging that this might not be the case for others. Interviewee B gave some examples of the connections between technology and teaching style in terms of the technologies that he did not use. He suggested that:

Certain things suit your own style and certain things don't suit it and you have to get to know what those are. If you are not an orator then podcasting is not for you, it's just not a way of doing stuff. I don't get on particularly well with blogs, mostly because I find them gossipy rather than, I just, it's not for me. (B) 
In these examples, technology was discussed not as a generic solution to problems but rather as a personal choice or style that may or not be appropriate for anyone else.

Technology was also seen to have had a role in changing teachers' personal teaching styles. Interviewee $\mathrm{J}$ described how she had become "a very different type of lecturer" since the introduction of PowerPoint:

I used actually to script my lectures with almost like a film script so with pauses and timers on the pages and these days I have got everything on PowerPoint and I actually ad lib around them and I found it frustrating at first, PowerPoint, it was not as detailed but on the other hand I think in many ways it is much more realistic to what people can actually absorb during a lecture. (J)

Interviewee $\mathrm{J}$ described a habit of using PowerPoint in a particular way. She described a "visual language" of layout and colour-coded words in her PowerPoint slides to "visually distinguish between what is the main point and what I want to say about it" (J). Sometimes she coloured terms relating to a particular concept being discussed in the lecture and did not always explain this to students. At other times, she included rhetorical questions and "cliffhangers" to keep students thinking over coffee breaks,

This discussion of performance and style highlights the personal and individual nature of decisions about teaching. Such individual differences became particularly visible when teachers had, for whatever reason, to use a colleague's resources (e.g., a PowerPoint presentation). Thus, these examples demonstrate the role of technologies in aiding, or sometimes even shaping, an individuals' expression of their personality and character through their teaching.

\section{Caring: Technology and concern for students}

Some participants believed that technology helped them to share their commitment and concern for students. As described above, Interviewee B believed that through technology, his enthusiasm and excitement were able to be shared with his students. He believed that this was important because he wanted students to know that he cared about their learning and progress and he felt that "technology helps enormously with that sense of caring” (B).

Interviewee $\mathrm{H}$ also discussed using technology to communicate her care for students. In this case, a VLE page for final-year students was intended to create a "sense of community":

I'm trying to make it quite a homely space, familiar space ... give the page a personality, make it an extension of what you do with students in your lectures, make it warm, make it welcoming, make it fun. $(\mathrm{H})$

She described how she tried to help final-year students "release their anxiety about final assessments" by baking for each other and reflected this on her VLE by posting photographs in a "cake hero of the week" gallery.

Sharing their personality and care for students through their teaching was one way that teachers built relationships with their students. However, several participants thought technology was having a negative effect on interpersonal relationships for both teachers and students. Interviewee $\mathrm{E}$ expressed a fear of overusing technology at the expense of personal relationships, and some participants believed that increased use of technology would have a detrimental effect on students' interpersonal skills (interviewees $\mathrm{E}$ and $\mathrm{K}$ ). Interviewee A noted how students' comments were received differently via email or discussion boards than face-to-face exchanges, while Interviewee $G$ believed that only using technology to interact with students would reduce both the "warmth" of her relationship with her students and the emotional impact of her teaching. The belief that technology could affect interactions with students also applied to interactions with teachers. For example, Interviewee D spoke of the distancing effect of colleagues in the same building conversing via email rather than in person. 
While all participants valued the use of technology to communicate with students, they identified problems associated with this. Interviewee $\mathrm{J}$ made it clear that she did not believe that email or online communication could replace face-to-face contact and was concerned that students had unrealistic expectations for instant replies to emails. Interviewee $\mathrm{K}$ suggested that, even though he knew it was counterproductive, he could not resist checking and answering his emails too frequently. While Interviewee $G$ also found electronic communication very time-consuming:

It is very easy to get into the circle when you don't notice that you are working over $10,11,12$ hours a day so I had to remind myself, no today you are not going to do your emails. (G)

In such cases, using technology provided increased flexibility about where and when to work but also made them more accessible. This was even more the case for interviewees A and J, who were contacted by students through their mobile phones:

I often get called by a student at 11 o'clock at night or 2 o clock on a Saturday afternoon, that sort of thing. So that can be, which I don't mind too much. It can be, infiltrate your personal life a bit. (A)

In these situations, participants had to manage their personal lives and their role as a teacher. These different aspects of their identity were important, and participants differentiated between how they used technology in the different parts of their life. For Interviewee A, technologies were used at home to make life easier and quicker; however, in her teaching, technology was there to make things more interesting. As a result, she was particularly keen not to adopt Twitter:

There is no way I am going to get onto Twitter and start twittering and that sort of thing, I think that technology is taking over your life ... and I don't want them tweeting me, absolutely not, no. (A)

Participants also acknowledged that students saw technology differently when studying compared to in other parts of their life. This was particularly clear in the use of Facebook, which according to Interviewee A was seen by students as very separate from technologies used by the university. Some participants were able to make use of Facebook in their work; for example, Interviewee J, a course leader, saw her presence on Facebook as advantageous because it provided the students with a sense of her presence even though she did not directly teach them. Other participants had found Facebook more problematic. For Interviewee H, while early experiences of social media had been successful at building relationships, she later became uncomfortable with the conflicts and personal messages she was seeing on Facebook. This led to a conflict between her responsibilities as a professional and her personal life.

However, not all interviewees spoke in terms that implied that technology was determining changes in relationship. Interviewee B believed that any decline in interpersonal skills was not a result of using technology in university teaching:

It's naïve to believe that they come to university to learn social and interpersonal skills. They're getting that from their friends, from Facebook, that's not what we teach them (B)

This quotation emphasises that technology is used within social structures and practices both inside and outside higher education. Teachers recognised the role of technology in their lives and the lives of their students and how adopting certain technologies for teaching can blur the boundaries between work and home.

\section{Discussion}

The findings of this study demonstrate ways in which the values dimension of teacher identity is enacted through teaching practices. The participants in this study wanted to share their enthusiasm for their subject, 
their sense of humour and their care for their students and had developed individual teaching styles in order to do this. The data demonstrated the participants' sense of commitment and deep personal interest in their students which, as Lankveld et al. (2017) show, go "hand in hand" (p. 333) with their teacher identity. In addition, it complements research into school teaching that has shown that care for and about students is an important part of the work of teachers (O’Connor, 2008, p. 125).

However, participants differed in the extent to which they thought technology was helping them to share these values and, for some, a desire to reflect their personality and values in their teaching meant retaining more traditional teaching practices. In common with the participants in Hanson's (2009) research, the interviewees in this study were aware of the potential displacement effect that students' increased access to online sources of information could have and had a similar desire to protect their successful face-to-face teaching relationship with their students. However, while Hanson's interviewees were not yet prepared for the "repositioning” (p. 562) required as they adopted technology, some of the participants in this study had found ways of maintaining relationships through their uses of technology. The methods teachers found to share their personality were very varied and sometimes rather subtle. They included using the colours and design of PowerPoint slides or VLE pages, the tone of their emails or the use of intonation in video or audio recording. For these teachers, technology was allowing them to express their identity and share their enthusiasm and enjoyment of their subject. It is also possible that the ability to share their values may have had more farreaching effects. Smits and Voogt (2017) identify that online teachers who scored highly for student satisfaction were those who wrote longer and more complex messages and that one characteristic of these messages was that they communicated the teachers' personality and emotions. An area for future investigation would be to explore students' responses and awareness of some of these other methods of teachers sharing their personalities.

On the other hand, sometimes technology was seen as restricting a teachers' identity. Teaching online was seen by some participants as hampering meaningful discussion or debate. Veletsianos and Kimmons (2013) have identified that for some teachers, social media is not personal enough to maintain the relationship with students that they desire. The data here supports this and, in addition, shows that sometimes engaging with social media could directly challenge a teacher's self-image as a caring professional by causing conflict between their responsibilities as a teacher and their personal use of social media. Also, even when the impact on relationships with students was seen as positive, the participants noted that increasingly their relationship and communications with students had extended beyond their working hours and intruded into other parts of their life. In some cases, teachers that found a particular technology hindering their ability to express their identity resisted its use. This is similar to Westberry et al.'s (2015) study of teachers adopting videoconferencing who expressed "feelings of sadness and frustration" (p. 112) when they were unable to engage with students in the ways they wanted.

A particular feature of the interview data was the extent to which using technology became an expression of teacher identity through the performance of teaching. Crook and Cluley (2009) have noted how the teacher voice on a VLE is often distant or even abrupt. However, in this study, teachers expressed their voice through technology in a number of different ways, for example, their use of images or humour. This led to very personal decisions about technology and a view that certain technologies suited different teaching styles. This can be seen as both a rationale for choosing not to use certain technologies (because they do not fit a particular teaching style) but also as moderating claims about technology - this works for my teaching style, it might not work for you - and thus resisting attempts for top-down implementation of technologies. The connection between teaching style and technology was not always a one-way relationship. When new technologies were introduced, they were believed to affect teaching styles either through supporting existing approaches or by constraining them. Consequently, some participants thought that technologies (e.g., PowerPoint) had influenced the way they taught.

The data in this study has emphasised the emotional and affective factors that influence teachers' use of technology. Lankveld et al. (2017) have shown that teacher's identity is formed in relation to their context, and this data highlights the importance of both technology and the student context. It provides further evidence that using technology could sometimes be perceived as a challenge to a teachers' role (Bakioglu \& 
Hacifazlioglu, 2007). However, while this has previously been expressed in terms of a challenge to the role of information provider, this project has provided evidence of another challenge to participants' identities as teachers who care for their students. In addition, unlike the results of earlier studies (e.g., Hanson, 2009), the data shows that some teachers had found ways of using technology to help them express their identity. Several participants in this study held views of teaching as a performance that communicated their personality and built relationships with their students. The importance of sharing personality through technology when teaching has been overlooked in the literature on technology in higher education, and the evidence from this study suggests that those teachers who felt technology restricted the communication of their personality were reluctant to use it.

There are a number of limitations to this study. Uitto et al. (2015) notes that much research into emotions is from a Western cultural context; and the data presented here is limited to teachers in English universities. In addition, the data was collected from a self-selected sample of teachers who were willing to be interviewed about their teaching. This could imply that the sample were more engaged in teaching and learning than others and, possibly, more committed to students than some others. Also, although effort was made to ensure that the sample came from a range of subjects, experiences and institutions, the small size of the sample limited this range. Therefore, their responses should not be considered to be generalisable to the wider population. In addition, Day and Leitch (2001) suggest that different means used to access emotions elicit significant and qualitatively different results, hence further research is required using a range of methods, for example, narrative and autobiographical approaches. Notwithstanding this, the data gives examples that the issues raised by this article do affect some individuals and are worth further investigation and consideration.

\section{Conclusion}

Teachers in higher education express and perform their personality across different aspects of their practice (with varying degrees of success) including their use of technology. Several participants in this study described their teaching in terms of a performance, and decisions about using technology were influenced by the extent to which the technology would support their preferred teaching style and how it would be viewed by their audience of students. A key aspect of this teaching performance was the extent to which individuals felt that they could share their personality and care for students through using technology. While some individuals believed that they could share their personality when teaching with technology, others did not and this was an important factor in how satisfied they were about using technology. Teachers who feel that technology might hamper the communication of their personality or warmth will be reluctant to use technology, and this is often overlooked in the literature on technology adoption. In addition, using technology could lead to teachers facing challenges to their identity as teachers who care for their students. Social media, such as Facebook, could challenge the boundaries between teachers' home and work lives and prove an uncomfortable experience for teachers.

Further research is needed to identify the different ways that teachers view their personal style of teaching and to relate this to their context and the resources they use. There is also a need for more research into the ways in which teachers share their personality and care for students and into the consequences of teachers feeling unable to do this. Notwithstanding this, these findings have implications for both the design and implementation of educational technology. Designers of new educational innovations should be encouraged to consider how new technologies and media can include features that support teachers to share their personality and values when communicating with students and should try to avoid creating technologies that only afford a distant voice. At the institutional level, those responsible for strategic decisions about the introduction of new technologies should consider how any new technologies might impact on relationships between students and teachers. They should endeavour to promote technologies that are flexible enough to allow teachers to express their concern for students and ensure that communication protocols encourage this. In particular, institutional or departmental expectations for how technology is used must be flexible enough to allow teachers space to reflect their own teaching style and personality. There should also be support and guidance available to help teachers negotiate the increasingly blurred boundaries between personal and professional lives. Finally, educational developers and trainers should support teachers in developing the skills necessary to use 
technologies in ways that reflect their personality and provide opportunities for teachers to share how they communicate their values and personality through technology.

\section{References}

Bain, J. D., \& McNaught, C. (2006). How academics use technology in teaching and learning: understanding the relationship between beliefs and practice. Journal of Computer Assisted Learning, 22(2), 99-113. https://doi.org/10.1111/j.1365-2729.2006.00163.x

Bakioglu, A., \& Hacifazlioglu, O. (2007). Lecturers' and students' attitudes towards the use of technology in lectures: No taboos, more thinking. Paper presented at the ISATT 2007 Conference, Ontario, Canada.

Bates, T., \& Poole, G. (2003). Effective teaching with technology in higher education. San Francisco, CA: Jossey-Bass.

Becker, H. J., \& Ravitz, J. (1999). The influence of computer and Internet Use on teachers’ pedagogical practices and perceptions. Journal of Research on Computing in Education, 31(4), 356-379. https://doi.org/10.1080/08886504.1999.10782260

Beijaard, D., Meijer, P. C., \& Verloop, N. (2004). Reconsidering research on teachers’ professional identity. Teaching and Teacher Education, 20(2), 107-128. https://doi.org/10.1016/j.tate.2003.07.001

Bennett, S., Agostinho, S., \& Lockyer, L. (2015). Technology tools to support learning design: Implications derived from an investigation of university teachers' design practices. Computers \& Education, 81, 211220. https://doi.org/10.1016/j.compedu.2014.10.016

British Educational Research Association. (2011). Ethical guidelines for educational research. Retrieved from https://www.bera.ac.uk/researchers-resources/publications/ethical-guidelines-for-educationalresearch-2011

Buchanan, T., Sainter, P., \& Saunders, G. (2013). Factors affecting faculty use of learning technologies: Implications for models of technology adoption. Journal of Computing in Higher Education, 25(1), 1-11. https://doi.org/10.1007/s12528-013-9066-6

Campbell, K. (2005). Conflict, risk and authority: Female faculty members' stories of change. Technology, Pedagogy and Education, 14(3), 309-328. https://doi.org/10.1080/14759390500200209

Charmaz, K. (2006). Constructing grounded theory: A practical guide through qualitative analysis. London: Sage.

Clegg, S. (2011). Academic identities re-formed? Contesting technological determinism in accounts of the digital age. Contemporary Social Science, 6(2), 175-189. https://doi.org/10.1080/21582041.2011.583485

Crook, C., \& Cluley, R. (2009). The teaching voice on the learning platform: Seeking classroom climates within a virtual learning environment. Learning, Media and Technology, 34(3), 199-213. https://doi.org/10.1080/17439880903141570

Day, C., Kington, A., Stobart, G., \& Sammons, P. (2006). The personal and professional selves of teachers: Stable and unstable identities. British Educational Research Journal, 32(4), 601-616. https://doi.org/10.1080/01411920600775316

Day, C., \& Leitch, R. (2001). Teachers’ and teacher educators’ lives: The role of emotion. Teaching and Teacher Education, 17(4), 403-415. https://doi.org/10.1016/s0742-051x(01)00003-8

Ferguson, P. (2004). Faculty beliefs about teaching with technology. In M. Simonson \& M. Crawford (Eds.), 27th Annual Proceedings of Selected Papers on the Practice of Educational Communications and Technology (Vol. 2, pp. 155-166). Retrieved from ERIC database. (ED499962)

Flick, U. (2009). An introduction to qualitative research (4th ed.). London: Sage.

Gonzalez, C. (2009). Conceptions of, and approaches to, teaching online: A study of lecturers teaching postgraduate distance courses. Higher Education, 57(3), 299-314. https://doi.org/10.1007/s10734-0089145-1

González, C. (2012). The relationship between approaches to teaching, approaches to e-teaching and perceptions of the teaching situation in relation to e-learning among higher education teachers. Instructional Science, 40(6), 975-998. https://doi.org/10.1007/s11251-011-9198-x

Goodyear, P. (2002). Teaching online. In N. Hativa \& P. Goodyear (Eds.), Teacher thinking, beliefs and knowledge in higher education (pp. 79-102). Dordrecht: Kluwer. 
Hanson, J. (2009). Displaced but not replaced: The impact of e-learning on academic identities in higher education. Teaching in Higher Education, 14(5), 553-564. https://doi.org/10.1080/13562510903186774

Hativa, N., \& Goodyear, P. (2002). Teacher thinking, beliefs and knowledge in higher education. Dordrecht: Kluwer.

Henkel, M. (2005). Academic identity and autonomy in a changing policy environment. Higher Education, 49(1/2), 155-176. https://doi.org/10.1007/s10734-004-2919-1

Hockings, C., Cooke, S., Yamashita, H., McGinty, S., \& Bowl, M. (2009). 'I'm neither entertaining nor charismatic ...' negotiating university teacher identity within diverse student groups. Teaching in Higher Education, 14(5), 483-494. https://doi.org/10.1080/13562510903186642

Johnson, D. R. (2012). Technological change and professional control in the professoriate. Science, Technology \& Human Values, 38(1), 126-149. https://doi.org/10.1177/0162243911430236

Kember, D., \& Kwan, K.-P. (2000). Lecturers' approaches to teaching and their relationship to conceptions of good teaching. Instructional Science, 28(5), 469-490. https://doi.org/10.1023/A:1026569608656

Kirkwood, A. (2009). E-learning: You don't always get what you hope for. Technology, Pedagogy and Education, 18(2), 107-121. https://doi.org/10.1080/14759390902992576

Kreber, C. (2010). Academics' teacher identities, authenticity and pedagogy. Studies in Higher Education, 35(2), 171-194. https://doi.org/10.1080/03075070902953048

Kregor, G., Breslin, M., \& Fountain, W. (2012). Experience and beliefs of technology users at an Australian university: Keys to maximising e-learning potential. Australasian Journal of Educational Technology, 28(8), 1382-1404. https://doi.org/10.14742/ajet.777

Lankveld, T. v., Schoonenboom, J., Volman, M., Croiset, G., \& Beishuizen, J. (2017). Developing a teacher identity in the university context: A systematic review of the literature. Higher Education Research \& Development, 36(2), 325-342. https://doi.org/10.1080/07294360.2016.1208154

Lynch, M. M. (2002). The online educator: A guide to creating the virtual classroom. London: RoutledgeFalmer.

McConnell, D. (2000). Implementing computer-supported cooperative learning (2nd ed.). London: Kogan Page.

McShane, K. (2004). Integrating face-to-face and online teaching: Academics' role concept and teaching choices. Teaching in Higher Education, 9(1), 3-16. https://doi.org/10.1080/1356251032000155795

Nevgi, A., \& Löfström, E. (2014). Visualisations as a means for exploring academics' teacher identities. International Journal for Academic Development, 19(3), 174-185. https://doi.org/10.1080/1360144x.2013.823545

Newland, B., \& Byles, L. (2014). Changing academic teaching with Web 2.0 technologies. Innovations in Education and Teaching International, 51(3), 315-325. https://doi.org/10.1080/14703297.2013.796727

Nixon, J. (1996). Professional identity and the restructuring of higher education. Studies in Higher Education, 21(1), 5-16. https://doi.org/10.1080/03075079612331381417

O’Connor, K. E. (2008). "You choose to care”: Teachers, emotions and professional identity. Teaching and Teacher Education, 24(1), 117-126. https://doi.org/10.1016/j.tate.2006.11.008

Owens, T. (2012). Hitting the nail on the head: The importance of specific staff development for effective blended learning. Innovations in Education and Teaching International, 49(4), 389-400. https://doi.org/10.1080/14703297.2012.728877

Perrotta, C. (2017). Beyond rational choice: How teacher engagement with technology is mediated by culture and emotions. Education and Information Technologies. 22(3), 789-804. https://doi.org/10.1007/s10639$\underline{015-9457-6}$

Roberts, G. (2003). Teaching using the Web: Conceptions and approaches from a phenomenographic perspective. Instructional Science, 31(1), 127-150. https://doi.org/10.1023/a:1022547619474

Roche, L. A., \& Marsh, H. W. (2000). Multiple dimensions of university teacher self-concept: Construct validation and the influence of students' evaluations of teaching. Instructional Science, 28(5-6), 439-468. https://doi.org/10.1023/A:1026576404113

Shelton, C. (2014). "Virtually mandatory": A survey of how discipline and institutional commitment shape university lecturers’ perceptions of technology. British Journal of Educational Technology, 45(4), 748759. https://doi.org/10.1111/bjet.12051

Shelton, C. (2018). An ecological model for university teachers' thinking about technology. Journal of Computing in Higher Education. https://doi.org/10.1007/s12528-018-9168-2 
Skelton, A. (2012a). Teacher identities in a research-led institution: In the ascendancy or on the retreat? British Educational Research Journal, 38(1), 23-39. https://doi.org/10.1080/01411926.2010.523454

Skelton, A. (2012b). Value conflicts in higher education teaching. Teaching in Higher Education, 17(3), 257268. https://doi.org/10.1080/13562517.2011.611875

Smits, A., \& Voogt, J. (2017). Elements of satisfactory online asynchronous teacher behaviour in higher education. Australasian Journal of Educational Technology, 33(2), 97-114. https://doi.org/10.14742/ajet.2929

Steel, C. (2003). Investigating concept mapping and stimulated recall to reveal academic teacher beliefs and how they are enacted through learning designs for the Web. In D. Lassner \& C. McNaught (Eds.), Proceedings of ED-MEDIA 2003-World Conference on Educational Multimedia, Hypermedia \& Telecommunications (pp. 2217-2224). Waynesville, NC: Association for the Advancement of Computing in Education. Retrieved from https://www.learntechlib.org/j/EDMEDIA/v/2003/n/1/

Steel, C. (2006). Influence of teacher beliefs on web-enhanced learning experiences: Learners and teachers. In L. Markauskaite, P. Goodyear, \& P. Reimann (Eds.), Proceedings of the 23rd Annual Ascilite Conference: Who's learning? Whose technology? (pp. 795-805). Sydney: The University of Sydney. Retrieved from http://www.ascilite.org/conferences/sydney06/proceeding/pdf_papers/vol2.pdf

Steel, C. (2009). Reconciling university teacher beliefs to create learning designs for LMS environments. Australasian Journal of Educational Technology, 25(3), 399-420. https://doi.org/10.14742/ajet.1142

Uitto, M., Jokikokko, K., \& Estola, E. (2015). Virtual special issue on teachers and emotions in Teaching and teacher education (TATE) in 1985-2014. Teaching and Teacher Education, 50, 124-135. https://doi.org/10.1016/j.tate.2015.05.008

Veletsianos, G., \& Kimmons, R. (2013). Scholars and faculty members' lived experiences in online social networks. The Internet and Higher Education, 16, 43-50. https://doi.org/10.1016/j.iheduc.2012.01.004

Westberry, N., McNaughton, S., Billot, J., \& Gaeta, H. (2015). Resituation or resistance? Higher education teachers' adaptations to technological change. Technology, Pedagogy and Education, 24(1), 101-116. https://doi.org/10.1080/1475939X.2013.869509

Yin, R. K. (2003). Case study research: Design and methods (3rd ed.). London: Sage.

Corresponding author: Chris Shelton, c.shelton@chi.ac.uk

Australasian Journal of Educational Technology @ 2018.

Please cite as: Shelton, C. (2018). "You have to teach to your personality": Caring, sharing and teaching with technology. Australasian Journal of Educational Technology, 34(4), 92-106.

https://doi.org/10.14742/ajet.3557 